\title{
ANALYSIS OF FACTORS AFFECTING INDONESIAN COFFEE EXPORTS IN 2001-2018 USING THE VECTOR AUTOREGRESSION [VAR] APPROACH
}

\author{
Diandra Locita Sari ${ }^{1^{*}}$ \\ Sugeng Hadi Utomo ${ }^{2}$ \\ Agus Sumanto ${ }^{3}$ \\ 1, 2, 3 Faculty of Economics, State University of Malang \\ E-mail: Locita.laras6@gmail.com ${ }^{1}$, sugeng.hadi.fe@um.ac.id ${ }^{2}$, agus.sumanto.fe@um.ac.id ${ }^{3}$ \\ ${ }^{*}$ Correspondence: Locita.laras6@gmail.com ${ }^{1}$
}

Submitted: 17 November 2021, Revised: 11 December 2021, Accepted: 14 December 2021

\begin{abstract}
Abstrak. Coffee exports are influenced by the exchange rate, the price of coffee and the amount of production. The purpose of the study was to determine the short-term and long-term relationship between coffee exports in 2001-2018. The research method is quantitative descriptive using classical assumption test and Error Correlation Model (ECM). The results of the VAR study are that coffee exports are not affected by coffee prices, coffee production and the rupiah exchange rate. Coffee exports were not significantly affected by coffee production, coffee prices and the exchange rate (exchange rate) using VAR. result Grangger's is that coffee production affects coffee exports and the exchange rate affects coffee exports. Test IRF and VD is the coffee production is influenced by coffee prices and the exchange rate, the price of coffee affects the production of coffee, coffee exports and the exchange rate and the exchange rate is influenced by the price of coffee and coffee exports. As for advice because coffee production affects coffee exports from Indonesia then, the government should do a vertical integration from upstream (people's plantations) to downstream (industries) to increase export expansion.
\end{abstract}

Keywords: coffee exports, exchange rates, coffee prices, coffee production, VAR. 


\section{INTRODUCTION}

In a country that adheres to an open economic system, it cannot be separated from international interactions, one of the activities of which is international trade which includes exports and imports. In the midst of increasing coffee consumption globally, the issue of coffee commodities should be a point of concern for the government. In the era of openness and trade liberalization, the flow of goods and services is getting higher and higher so that almost no country still uses a closed economic system. International trade has a very important influence on economic development, especially in seeking funds to finance the increasing development (Purba et al., 2021). Local coffee farmers object to the policy, as it tends to under-asses the quality for foreign exchange of its coffee. This is more because small and mediumsized businesses do not have adequate processing technology. In addition, the raw materials and products needed by industry and society cannot be entirely met domestically, sometimes they have to bring in goods from abroad (imported) to meet domestic needs. Then the goods produced in the country will also need to share the broader market, namely the foreign markets (exports) which is intended as income countries (foreign exchange)

In a year the coffee harvest is only once. Farmers will face the challenge of managing the expenditures obtain from the coffee harvest. Usually if not in the harvest period, coffee farmers turn to other businesses such as growth bananas to become traders.
Indonesia is currently increasing production of oil and gas exports and nonoil in order to improve the competitiveness in international trade so as to increase revenue nationally. Coffee is one of Indonesia's export commodities that generates quite high foreign exchange (Nanda et al., 2018), because coffee is a drink that contains quite a lot of benefits with balanced consumption so that it is popular in the world. Indonesia's coffee exports in 2010-2013 were 433600 tons, 346500 tons, 448600 tons, and 534000 tons. The Export value of coffee is $\$ 983998$, $\$ 1303494, \$ 1566805$ and $\$ 1468261$ (Badan Pusat Statistik, 2013). But at the present time decreased Indonesian coffee exports to the united states as much as $34 \%$ from January to November 2018 to USD $\$ 734,73$ million (Badan Pusat Statistik, 2019). One of causes in the price of coffee is local more expensive than international coffee costs as Vietnam USD \$1900/tons, and exporters prefer to sell coffee in domestic (Kontan.co.id, n.d.)

Some factor can cause the export of coffee in Indonesia, among others:

1. The increase in coffee production by smallholders and state / private causes the fulfillment of consumption and price stability coffee, so that it can export coffee,

2. price of coffee is expensive due to production inefficiencies that Indonesia's low coffee exports reduce the country's foreign exchange, and

3. The depreciation of the rupiah increases coffee exports causing an increase in foreign exchange. 
561 | Analysis of Factors Affecting Indonesian Coffee Exports in 2001-2018 Using The Vector Auto regression (VAR) Approach

The focus of this study is to describe the dynamic relationship of coffee exports that are influenced by coffee prices, coffee production and the rupiah exchange rate using analysis Vector Auto regression (VAR), and describe the relationship between shock and forecasting on coffee production, coffee prices and exchange rates affecting coffee exports in 2001-2018

\section{International Trade International}

Trade is a buying and selling transaction between several parties involving more than one country. International trade itself can be carried out by individuals or groups using foreign currency as a means of payment. When a country carries out export and import activities in international trade, it generates profits. According to (Salvatore, 2014) research states there are 3 theories about the advantages of international trade

\section{Profit Theory Absolute by Adam Smith}

There is an absolute advantage that the state has in producing goods efficiently so that it can exchange these goods to countries that experience absolute losses due to inefficiency in producing goods, so that both countries benefit. An example is to produce one unit of American grain and clothing requires 8 and 4 workers. In the UK every unit of grain and clothing, need to employ as many as 10 and 2. Then the superior American absolute on wheat and English have advantages in clothing (Bagaskoro \& Imansyah, 2019).

2. Theory of Advantage Comparative by David Ricardo

Every country can gain comparative advantage if it can make efficiency in the product that has the smallest absolute loss and import the product that has the largest absolute loss. America would specialize in wheat and import clothing from Britain (Siddiqui, 2018).

3. Heckscher-Ohlin Theory

Heckscher-Ohlin Theory is that there is exporting of scarce and expensive factors of production and importing of cheap and cheap factors of production. For example, developed countries export capital and technology to developing countries and developed countries import low-paid labor. The assumptions of the Heckscher-Ohlin theory include: Two countries, two commodities, and two factors of production, Both countries use the same technology, The same commodity is labor-intensive in two countries, The returns to scale are constant, Full specialization in production, Equal tastes in both countries, Perfect competition in both commodity and factor markets, Perfect mobility of factors of production internally within a country but not internationally, No transportation costs, tariffs, or other barriers to the free flow of international trade, All resources are fully utilized, and Balanced trade.

\section{Export}

Export is the process of sending goods abroad so as to increase national income which has an impact on increasing production and employment (Salvatore, 2014). Coffee exporters must register with the state because coffee exports are 
commodities that are regulated in exports according to the regulation of the Minister of Trade Number 01/M-DAG/PER/1/2007 dated January 22, 2007. The supply factor for coffee exports is influenced by the price of coffee and the amount of coffee sold. The law of supply basically states that: the higher the price of an item, the more quantity of the item will be offered by sellers in a Cateris Paribus state (Sukirno, 2010). The supply of coffee according to (Sukirno, 2010) is influenced by product prices, namely the cheaper imported products cause import demand to increase and the more expensive export products increase, Production is a business or activity to increase the use (use value) of an item. The Function production is the maximum amount of output that can be produced from the use of a number of inputs using certain technologies (Antara, n.d.), and Other goods, namely for complementary goods that are substitutes, are the increasing number of goods substitute (tea) resulting in increased consumption of coffee and other goods are complementary (sugar), namely the high price of sugar causes low coffee consumption.

\section{Exchange Rate}

Exchange rate is the price of a currency of a country which is measured or expressed in another currency and is able to affect exports (Krugman, 1993). According to (Sukirno, 2010), the increase in exchange rates against the currencies of the importing country and exporting countries may increase the purchasing power of importing countries resulting in exports from the country of exporting increased Economists distinguish the exchange rate into two, namely the nominal exchange rate and the real exchange rate. The real exchange rate is the price level of goods that can be traded by a country for goods from other countries and the nominal exchange rate is the price of the currency at the existing exchange rate (Indahsari, 2020).

\section{Research Hypothesis}

Effect of Coffee Production on Indonesian Coffee Exports

There is a significant positive relationship between coffee production and coffee exports, so that an increase in coffee production can increase coffee exports. Factors that affect coffee production are the rising coffee price, which makes the supply of coffee high and the high cost of substitute goods (substitute goods such as tea) makes the motivation of producers to produce coffee high (Torga \& Spers, 2020). This is supported by research by (Navulan Sari \& Nur Syechalad, 2013)

Effect of Coffee Prices on Indonesian Coffee Exports

There is a significant negative relationship between coffee prices and coffee exports to America so that cheap coffee prices lead to an increase in coffee exports. The state will gain competitive advantage absolute and excellence comparatively when the price of the export product is cheap. This is different from research supported by research by (Navulan Sari \& Nur Syechalad, 2013).

Affects Exchange Rate Indonesian Coffee Exports

There is a significant negative 
563 | Analysis of Factors Affecting Indonesian Coffee Exports in 2001-2018 Using The Vector Auto regression (VAR) Approach

relationship between the exchange rate and coffee exports so that the increase in coffee exports causes an increase in coffee exports to America. The depreciation of the rupiah has increased the purchasing power of Americans to buy Indonesian coffee because it is cheaper. This is supported by (Arwa, 2020).

\section{METHODS}

\section{The Design and Data Collection Methods}

The design and type of research in this study used quantitative descriptive methods. This study uses quantitative methods because it uses secondary data in the form of numbers, namely the variable dependent is coffee exports $(Y)$ and the variables independent are coffee prices (X1), coffee production (X2) and exchange rates (exchange rates) (X3). The research location was in Indonesia from 2001 to 2018. The type of data used in this study was quantitative secondary data or time series. Secondary data sources are data sources that are obtained directly from a second party using documentation techniques in the form of documents in the form of files obtained from the Central Statistics Agency (BPS) (Badan Pusat Statistik, 2019).

\section{Data Analysis}

1. Classical Assumption Test

According to (Agunbiade \& Adeboye, 2012) states the Classical Assumption test to produce BLUE data which consists of: a) Normality test aims to test normally distributed data using jarque fallow and prob below $0.05, \mathrm{~b}$ )
Multicollinearity test to test the occurrence of correlation between variables by looking at the determination of $\mathrm{R}$ must be below 0.85 , c) Autocorrelation test the impact of time differences on the data using Durbin Watson. If the DW value is below -2 , it means that there is a positive autocorrelation. If the DW value is between -2 to +2 , it means that there is no autocorrelation. If the DW value is above +2 , it means that there is a negative autocorrelation, and d) Heteroscedasticity test to determine the difference in variance in the residual data. The Uses test the White test so that if the value is more than 0.05 then there is a problem with heteroscedasticity.

2. Vector Auto regression (VAR) Test

According to research by (Mukhlis \& Simanjuntak, 2017), the test Vector Auto regression (VAR) is forecasting on time series data and analyzing one variable that is influenced by random disturbances that have a dynamic impact. Steps to perform the VAR test include: a)Test Stationarity is to determine the root of the root of the data is examined using the ADF test on the value of $t$-statistic ADF equal to test critical value, b) Test Co-integration Johanson was to determine the longterm relationship between variables is co-integrated when the Maximum Eigenvalue test and the Trace test must higher than the critical value, c) The Test VAR Estimation uses a partial test by comparing the value of T-Table > TCalculate and prob $<0.05$ so that there is a significant relationship, d)Test 
Optimal Lag by looking for the smallest value on ICE, SC and HQ, e) Causality Grengger to determine the causal relationship between variables, f) Impulse Response (IRF) test to determine the effect of shock between one variable affecting other variables, and g)test varience Decomposition (VD) is to determine the dynamic forecasting between variables when there is a change in variables

RESULTS AND DISCUSSION

Table 1. Test Descriptive Statistics

\begin{tabular}{|c|c|c|c|c|}
\hline & $\begin{array}{l}\text { PRODUCTION OF } \\
\text { Coffee }\end{array}$ & EXCHANGE & $\begin{array}{l}\text { PRICE OF } \\
\text { Coffee }\end{array}$ & $\begin{array}{l}\text { EXPORT OF } \\
\text { Coffee }\end{array}$ \\
\hline Mean & $\begin{array}{l}10935.17 \\
22058.87 \\
8472610 .\end{array}$ & & & 667739.1 \\
\hline Median & $\begin{array}{l}9750,000 \\
20775.53 \\
7352772 .\end{array}$ & & & 676178.5 \\
\hline Maximum & $\begin{array}{r}14481.00 \\
40507.51 \\
17191221\end{array}$ & & & 716089.0 \\
\hline Minimum & $\begin{array}{l}8465,000 \\
5823,920 \\
168512.7\end{array}$ & & & 569234.0 \\
\hline
\end{tabular}

Source: The result of sports data by using e-views

Descriptive statistical test results are 1) Export of coffee is an activity of selling coffee to the international market and foreign exchange will be included in the credit cash in the trade balance (Sukirno, 2004). Based on descriptive statistical tests, it can be seen that the highest coffee export value was $\$ 1249,520,000$ in 2012 and the lowest coffee export was $\$ 188,4930,000$ in. 2) Coffee production is an activity to add value to coffee by utilizing input factors and technology (Sukirno, 2004). The maximum coffee production in 2017 was 716089 and the minimum production in 2001 was 569234. 3) Rising coffee prices led to high supply and low demand (Sukirno, 2004). The highest coffee price was 40507,514 rupiah in 2018 and the lowest coffee price in 2001 was 6705 rupiah. 4) Exchange Rate (Exchange Rate) is the price of a currency from a country which is measured or expressed in another currency (Sukirno, 2011) The highest exchange rate was 14481.00 rupiah in 2017 and the lowest exchange rate was 8465,000 in 2002.

\section{Data Analysis}


565 | Analysis of Factors Affecting Indonesian Coffee Exports in 2001-2018 Using The Vector Auto regression (VAR) Approach

1. Classical Assumption

Test The classical assumption test consists of 4 tests to declare the data BLUE, namely Normality test to find out the data is normally distributed because the jarque value is $36,21706>10,597$
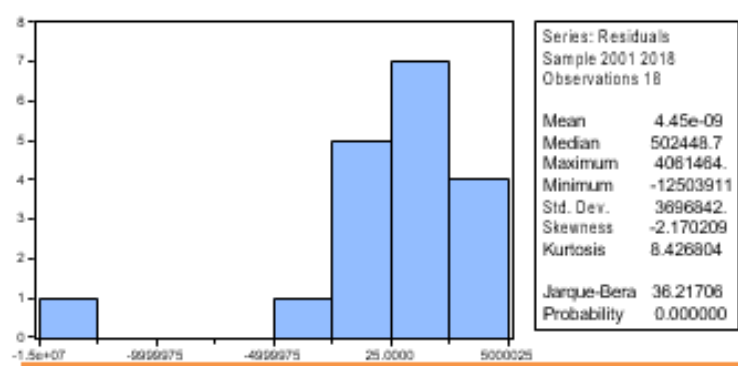

Multicollinearity because the value $0.896>0.85$ so that a high correlation to the price of coffee affects the export of coffee. Positive autocorrelation because the values of 1.407148 be between 0 and 1.5284, and There is a problem heteroscedasticity because the test Prob

\begin{tabular}{|c|c|c|c|}
\hline & Production of Coffee & Kurs & Price of Coffee \\
\hline Kurs & 0.267 & 1 & $\mathbf{0 . 8 9 6}$ \\
\hline Price of Coffee & 0.353 & $\mathbf{0 . 8 9 6}$ & 1 \\
\hline
\end{tabular}

and prob $0,00<0,05$. There

$0,2085>0.05$ on the White test.

Figure 1. Test Normality

2. Test Vector Auto regression (VAR)

a. Test Stationarity Data

The test Stationarity data using the ADF unit root tests (Augmented Dickey-Fuller Test) to see whether the data is stationary or not. Coffee exports, coffee production, coffee prices, and exchange rates are stationary because the T-Statistics are $-3.480528,-3.480528,-4.296144$, and -4.319316 which are lower than the critical value -3.959148 and 3.920350 at the first different and $1 \%$ level.

Table 2. Test Root

\begin{tabular}{|c|c|c|c|}
\hline \multicolumn{4}{|c|}{ Null Hypothesis: D(EXPORT) has a unit root } \\
\hline & & t-Statistic & Prob.* \\
\hline \multicolumn{2}{|c|}{ Augmented Dickey-Fuller test statistic } & -3.480528 & 0.0232 \\
\hline \multirow[t]{2}{*}{ Test critical values: } & $1 \%$ & -3.920350 & \\
\hline & level & & \\
\hline \multicolumn{4}{|c|}{ Null Hypothesis: D(HARGAKOPI) has a unit root } \\
\hline & & t-Statistic & Prob.* \\
\hline \multicolumn{2}{|c|}{ Augmented Dickey-Fuller test statistic } & -4.296144 & 0.0054 \\
\hline \multirow[t]{2}{*}{ Test critical values: } & $1 \%$ & -3.959148 & \\
\hline & level & & \\
\hline
\end{tabular}


Null Hypothesis: D(COFFEE PRODUCTION) has a unit root

\begin{tabular}{|c|c|c|c|}
\hline & & t-Statistic & Prob.* \\
\hline \multicolumn{2}{|c|}{ Augmented Dickey-Fuller test statistic } & -6.142305 & 0.0002 \\
\hline \multirow[t]{2}{*}{ Test critical values: } & $1 \%$ & -3.920350 & \\
\hline & level & & \\
\hline \multicolumn{4}{|c|}{ Null Hypothesis: D(EXCHANGE) has a unit root } \\
\hline & & $\mathrm{t}$-Statistic & Prob.* \\
\hline \multicolumn{2}{|c|}{ Augmented Dickey-Fuller test statistic } & -4.319316 & 0.0047 \\
\hline \multirow[t]{2}{*}{ Test critical values: } & $1 \%$ & -3.920350 & \\
\hline & level & & \\
\hline
\end{tabular}

Source: The result of sports data by using e-views

b. Co-integration

The Co-integration test is used to test whether or not the relationship is using the test Johanson. The result is that there is a relationship between coffee prices, coffee production and exchange rates on coffee exports because Eigenvalue and Max Eingen Statistics > Critical Value, namely: a) None has $0.825726+27.95399>$ 27.58434 .

Table 3. Test Co-integration Johansen

\begin{tabular}{ccccc}
\hline \multicolumn{3}{l}{ Unrestricted Co-integration Rank Test (Maximum Eigenvalue) } \\
\hline Hypothesized & $\begin{array}{c}\text { Max- } \\
\text { Eigen }\end{array}$ & $\mathbf{0 . 0 5}$ & \\
\hline No. of CE(s) & Eigenvalue & Statistical & $\begin{array}{c}\text { Critical } \\
\text { Value }\end{array}$ & Prob.* $^{* *}$ \\
\hline None * & $\mathbf{0 . 8 2 5 7 2 6}$ & $\mathbf{2 7 . 9 5 3 9 9}$ & $\mathbf{2 7 . 5 8 4 3 4}$ & $\mathbf{0 . 0 4 4 9}$ \\
\hline
\end{tabular}

Source: The result of sports data by using e-views

c. Vector Auto regression (VAR) Test.

The result of the test Vector Auto regression (VAR) is that Coffee Exports affect the Exchange Rate because the T-Table value is
[1.87975]> The count is 1.771, b) $C$ affects the coffee export because the T-Table value is [3.76039] > The count is 1.771 , and c) $C$ affects the exchange rate because the value T-Table [ 2.33358] > Count 1.771

Table 4. Test VAR

\section{Vector Auto regression Estimates}

\section{Coffee Exports}

Coffee

[ 1.51328]
Production Coffee

[-0.16349]
Exchange

[ 1.87975]
Price Coffee 
567 | Analysis of Factors Affecting Indonesian Coffee Exports in 2001-2018 Using The Vector Auto regression (VAR) Approach

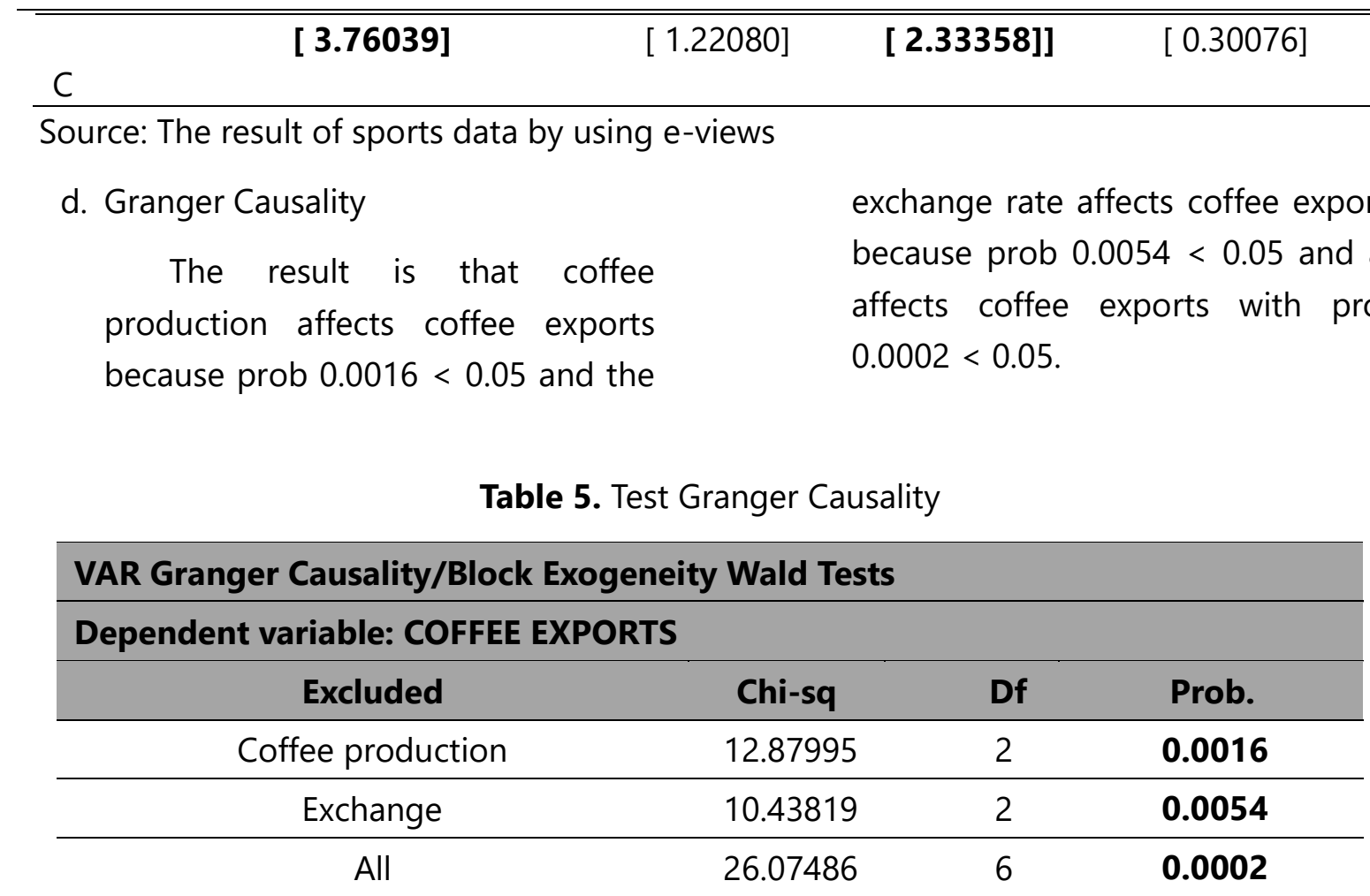

Source: The result of sports data by using e-views

e. Impulse Response Function (IRF)

The results of the test Impulse Response Function (IRF)are 1) Coffee exports are influenced by coffee production, exchange rates and coffee prices in period 1 because prob $0.00<0.05,2)$ Coffee production is influenced by exchange rates and coffee prices in period 1 because prob $0.00<0.05$, and 3) Exchange rate is affected by coffee prices in period 1 because prob 0.00 $<0.05$.

Table 6. Test Impulse Responses Function

\begin{tabular}{ccccc}
\hline \multicolumn{5}{c}{ Response of Export Of Coffee: } \\
\hline Period & $\begin{array}{c}\text { Coffee } \\
\text { exports }\end{array}$ & $\begin{array}{c}\text { Coffee } \\
\text { production }\end{array}$ & Exchange & Coffee rates \\
\hline 2496052. & 1 & $\mathbf{0 . 0 0 0 0 0 0}$ \\
$\mathbf{0 . 0 0 0 0 0 0}$ & $\mathbf{0 . 0 0 0 0 0 0}$ \\
\hline Period & Of coffee & $\begin{array}{c}\text { Production } \\
\text { coffee }\end{array}$ & Exchange & Coffee rates \\
\hline$-4414,327$ & \multicolumn{5}{c}{$\mathbf{0 . 0 0 0 0 0 0}$} \\
27807.21 & & $\mathbf{0 . 0 0 0 0 0 0}$ & \\
\hline
\end{tabular}

Response of Exchange:

Period Of coffee Production Exchange Price coffee




\begin{tabular}{|c|c|c|c|c|}
\hline & export & coffee & & \\
\hline 1 & 14.80972 & 77.33384 & 957.3450 & 0.000000 \\
\hline
\end{tabular}

Source: The result of sports data by using e-views

f. Variance Decomposition (VD)

The results of the research are a) Coffee exports are influenced by coffee production, exchange rates and coffee prices in period 1 with prob $0.00<0.05$, b) Coffee production is influenced by exchange rates and coffee prices in period 1 with prob $0.00<0.05$, and c) The exchange rate is influenced by coffee exports with prob $0.023770<0.05$ and coffee prices with prob $0.00<$ 0.05 in period 1.

Table 7. Test Variance Decomposition

\begin{tabular}{|c|c|c|c|c|c|}
\hline \multicolumn{6}{|c|}{ variance decomposition of coffee exports: } \\
\hline \multirow[b]{2}{*}{ period } & \multicolumn{5}{|c|}{ production } \\
\hline & Se & $\begin{array}{l}\text { exports } \\
\text { coffee }\end{array}$ & $\mathbf{i}$ & exchange & $\begin{array}{l}\text { price } \\
\text { coffee }\end{array}$ \\
\hline 1 & ofof2496052. & 100.0000 & 0.000000 & 0.000000 & 0.000000 \\
\hline \multicolumn{6}{|c|}{ variance decomposition of production: } \\
\hline & & & oroduction & & \\
\hline period & $\mathrm{Se}$ & $\begin{array}{l}\text { coffee } \\
\text { exports } \\
\text { coffee }\end{array}$ & i & exchange & $\begin{array}{l}\text { coffee } \\
\text { price }\end{array}$ \\
\hline 1 & 28155.41 & 2.458133 & 97.54187 & 0.000000 & 0.000000 \\
\hline \multicolumn{6}{|c|}{ variance decomposition of exchange: } \\
\hline period & $\mathrm{Se}$ & $\begin{array}{c}\text { coffee } \\
\text { exports } \\
\text { coffee }\end{array}$ & $\begin{array}{l}\text { duction } \\
\text { coffee }\end{array}$ & exchange & price \\
\hline 1 & 960.5775 & 0.023770 & 0.648148 & 99.32808 & 0.000000 \\
\hline
\end{tabular}

Source: The result of sports data by using e-views

\section{DISCUSSION}

\section{Relationship between Coffee Exports and Coffee Production}

Based on the VAR test, it was found that coffee production did not affect coffee exports in periods 1 and 2. The increase in coffee production did not the impact

The increase in coffee exports is caused by the high consumption of Indonesian people so that coffee production is to meet domestic needs rather than exports to foreign countries. This is different from the research of (Navulan Sari \& Nur Syechalad, 2013). According to research by (Navulan Sari \& Nur Syechalad, 2013) explaining the export volume of Aceh Arabica coffee is influenced by the exchange rate, the increase in Acehnese Arabica coffee production and overseas coffee prices. According to (Galih \& Setiawina, 2014) research, the increase in 
569 | Analysis of Factors Affecting Indonesian Coffee Exports in 2001-2018 Using The Vector Auto regression (VAR) Approach

the amount of production increases coffee exports.

Based on the results of the Causality test Grengger, Impulse Response Function (IRF) and Variance Decomposition (VD) stated that coffee production affects coffee exports. The reason is that according to Ohlin's Helic Theory, Indonesia has a comparative advantage that is efficient in production costs so that coffee prices are cheap (Salvatore, 2014). The results of the test Impulse Response Function (IRF) and Variance Decomposition (VD) are that coffee production is influenced by the exchange rate and coffee prices in period 1 because the more expensive the price increases the supply (Sukirno, 2011) .

\section{The Relationship Between Coffee Exports and Coffee Prices}

Based on the VAR test results, it is known that coffee prices in periods 1 and 2 do not affect coffee exports. The increase in coffee prices causes a low demand for coffee because consumers consume tea as a substitute good (Sukirno, 2004). This is similar to (Kustiari, 2007) which states that the decline in coffee exports in Indonesia is caused by the low value of Indonesian exports in the United States, Japan and Germany due to high coffee prices.

Based on the test results of Impulse Response Function (IRF) and Variance Decomposition (VD) said coffee prices affecting coffee production, When the price of coffee has increased causing manufacturers are motivated to produce coffee with cost efficiency of production (Sukirno, 2004).

Relationship between the Export of

\section{Coffee With Exchange Rate}

Based on the results of the VAR test, it is known that the increase in the exchange rate (exchange rate) has no effect on the increase in coffee exports in periods 1 and 2. The depreciation of the rupiah causes a negative impact in the form of an increase in coffee prices due to an increase in production costs caused by an increase in imported coffee raw materials and an increase in wages workers (Sukirno, 2004) This is different from research by (Cahyadi \& Sukarsa, 2014) which explains that rupiah appreciation and production cost efficiency can increase paper exports to the United States.

Based on the results of the Causality tests Grengger, Impulse Response Function (IRF) and Variance Decomposition (VD), it is stated that the exchange rate affects coffee exports because the depreciation of the rupiah increases exports. Based on the results of the Impulse Response Function (IRF) and Variance Decomposition (VD) it is stated that the exchange rate is influenced by coffee prices and coffee exports. The decline in the exchange rate was influenced by low coffee exports due to high coffee prices.

\section{CONCLUSIONS}

Coffee exports were not significantly affected by coffee production, coffee prices and the exchange rate using VAR. result Grangger's is that coffee production affects coffee exports and the exchange rate affects coffee exports. Test IRF and VD is the coffee production is influenced by coffee prices and the exchange rate, the price of 
coffee affects the production of coffee, coffee exports and the exchange rate and the exchange rate is influenced by the price of coffee and coffee exports. As for advice because coffee production affects coffee exports from Indonesia then, the government should do a vertical integration from upstream (people's plantations) to downstream (industries) to increase export expansion. And also provides various business funding programs to facilitate capital through financial inclusion and partnerships with the private sector so as to maintain quality coffee production without having to worry about production costs that are feared to suddenly increase, and there is also the development of integrated smallholder plantation development so as to increase production. Coffee is increasing and also quality without being affected by price and exchange rate.

\section{REFERENCES}

Agunbiade, D. A., \& Adeboye, N. O. (2012). Estimation of Heteroscedasticity Effects in a Classical Linear Regression Model of a Cross-Sectional Data. Progress in Applied Mathematics, 4(2), 18-28.

http://dx.doi.org/10.3968/g3075

Antara, M. (n.d.). Analisis Pendapatan Usaha Tambak Bandeng Di Desa Lalombi Kecamatan Banawa Selatan Kabupaten Donggala. Jurnal Pembangunan Agribisnis (Journal of Agribusiness Development), 2(1).

ARWA, S. H. (2020). Analisis Faktor-Faktor Yang Mempengaruhi Volume Ekspor Kopi Di Indonesia Periode 2013-2018
Perspektif Ekonomi Islam. UIN Raden Intan Lampung.

Badan Pusat Statistik. (2013). Badan Pusat Statistik. https://www.bps.go.id/

Badan Pusat Statistik. (2019). Statistik Kopi Indonesia 2019. Badan Pusat Statistik. https://www.bps.go.id//publication/2 020/12/02/de27ead7c1c7e29fd0aa95 0d/statistik-kopi-indonesia-2019.html

Bagaskoro, M. N., \& Imansyah, M. H. (2019). Pengaruh Ekspor Impor Terhadap Transaksi Berjalan Indonesia Sebelum Dan Sesudah Subprime Mortgage. JIEP: Jurnal Ilmu Ekonomi Dan Pembangunan, 2(2), 332-345. https://doi.org/10.20527/jiep.v2i2.117 6

Cahyadi, N. M. A. K., \& Sukarsa, M. (2014). Faktor-faktor yang mempengaruhi ekspor kertas dan barang berbahan kertas di Indonesia tahun 1988-2012. E-Jurnal Ekonomi Pembangunan Universitas Udayana, 4(1), 1-70.

Galih, A. P., \& Setiawina, N. D. (2014). Analisis pengaruh jumlah produksi, luas lahan, dan kurs dolar amerika terhadap volume ekspor kopi Indonesia periode tahun 2001-2011. E-Jurnal Ekonomi Pembangunan Universitas Udayana, 3(2), 44407.

Indahsari, N. N. (2020). Pengaruh Variabel Makroekonomi Terhadap Ekspor Hasil Hutan Indonesia ke Amerika Serikat Periode 2000-2017. Universitas Hasanuddin.

Kontan.co.id. (n.d.). kontan.co.id. kontan.co.id. https://www.kontan.co.id/

Krugman, P. (1993). Recent Thinking About 
571 | Analysis of Factors Affecting Indonesian Coffee Exports in 2001-2018 Using The Vector Auto regression (VAR) Approach

Exchange Rate Determination and Policyl Conference-1993.

Kustiari, R. (2007). Perkembangan pasar kopi dunia dan implikasinya bagi Indonesia.

Mukhlis, I., \& Simanjuntak, T. H. (2017). Ekonometrika Teori dan Aplikasi. Penerbit Cahaya Abadi. Tulungagung.

Nanda, T. R., Zulhelmi, Z., \& Syaryadhi, M. (2018). Perancangan Sistem Sortir Buah Kopi Berdasarkan Warna Dengan Teknik Citra Digital Berbasis Mikrokontroler Atmega 328p. Jurnal Karya Ilmiah Teknik Elektro, 3(2).

Navulan Sari, D., \& Nur Syechalad, M. (2013). Analisis Faktor-Faktor Yang Mempengaruhi Ekspor Kopi Arabika Aceh. Pascasarjana Universitas Syiah Kuala, 11(1), 11-21.

Purba, B., Rahmadana, M. F., Basmar, E., Sari, D. P., Klara, A., Damanik, D., Faried, A. I., Lie, D., Fazira, N., \& Rozaini, N. (2021). Ekonomi Pembangunan. Yayasan Kita Menulis.

Salvatore, D. (2014). Ekonomi Internasional Edisi Kesembilan. Jakarta: Penerbit Erlangga.

Siddiqui, K. (2018). David Ricardo's comparative advantage and developing countries: Myth and reality. International Critical Thought, 8(3), 426-452. https://doi.org/10.1080/21598282.20 18.1506264

Sukirno, S. (2004). Makro ekonomi teori pengantar edisi ketiga. Jakarta: Raja Grafindo Persada.

Sukirno, S. (2010). Pengantar Teori Makro
Ekonomi edisi ke tiga, PT. Raja Grafindo Persada, Jakarta.

Sukirno, S. (2011). Introduction to Macroeconomic Theory. Jakarta: PT. King Grafindo Persada.

Torga, G. N., \& Spers, E. E. (2020). Perspectives of global coffee demand. In Coffee Consumption and Industry Strategies in Brazil (pp. 21-49). Elsevier. https://doi.org/10.1016/B978-0-12814721-4.00002-0

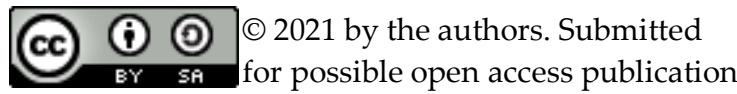
under the terms and conditions of the Creative Commons Attribution (CC BY SA) license (https://creativecommons.org/licenses/by-sa/4.0/). 